DOI https://doi.org/10.18551/rjoas.2017-06.36

\title{
COST-BENEFIT ANALYSIS OF WATERMELON PRODUCTION IN EKITI STATE, NIGERIA
}

Toluwase S.O.W.*, Owoeye R.S.

Department of Agricultural Economics and Extension Services, Ekiti State University, Nigeria ${ }^{*}$ E-mail: sunday.toluwase@eksu.edu.ng

\begin{abstract}
The study investigated the cost-benefit analysis of watermelon production in Ekiti State, Nigeria. One hundred and twenty watermelon producers were randomly selected from the study area. The main tool for data collection was questionnaire. Information on watermelon farmer's socio-economic characteristics, cost and return patterns, efficient use of factors of production and production pattern and resource combination that will increase outputs and revenue of farmers was sought from 120 respondents who were randomly selected. Data collected was analyzed using Gross margin analysis to determine the profitability level of watermelon production and stochastic frontier function to determine the efficiency level of watermelon production in the study area. The findings revealed that majority of the watermelon farmers adopted sole cropping system (65\%) while just 35\% intercrop with other crops. Those that adopted intercropping system intercrop with Cassava (66.67\%), Maize $(19.05 \%)$, Tomato $(9.52 \%)$ and Pepper $(4.76 \%)$. The specific reasons giving for intercropping are to increase income $(50 \%)$, to improve soil fertility $(7.14 \%)$, to reduce crop failure $(9.52 \%)$ and for optimum use of land (33.33\%). Most of the watermelon farmers plant their seed directly $(92.5 \%)$ while just $7.5 \%$ of the farmers adopt transplanting system. The Gross margin analysis shows that a net profit of \#75,114.68 was realized by the watermelon producers in the study area. The stochastic frontier function revealed that the co-efficient of farm size (1.05) was positive and significant at $10 \%$ which implies that a considerable increase in the size of the farm will lead to increase of $1.05 \%$ in yield. Also, the quantity of seeds has a negative co-efficient $(-2.73)$ as it is the quality of seeds that matters. Quality seeds in abundance quantity will increase outputs. It was recommended that the land acquisition system that makes it difficult for farmers to acquire enough agricultural should be reviewed to allow the farmers have more access to land for cultivation. Also Provision of improve seeds for cultivation should be made available to the farmers and Government grants and loans should be made easy to access as this will reduce the cost incurred on inputs and help provide funds for the production activities.
\end{abstract}

\section{KEY WORDS}

Watermelon, gross margin, stochastic frontier.

Water melon (Citrullus lanatus) is a plant species in the family cucurbitaceae (Schippers, 2000), a vine like flowering plant that scrambles and trail. It is originally from West Africa. The cultivation of water melon focuses on the production of fruits which can also be used as vegetables. It is highly medicinal fruits which has great advantages for the health system. With water melon's calories at $46 \%$ the fruit offer $20 \%$ vitamin C and $17 \%$ vitamin A. it supplies lycopene in way higher than tomatoes to fight free radicals. It relieves sore muscles and good for body hydration. The nutrients available in the seeds of water melon ward off cancer, the level of bad cholesterol in the body.

The dual functionality of water melon contributes to its economic viability. It contains about $6 \%$ sugar and $91 \%$ water. Like other fruits, it is a good supplier of vitamin C, low in fat and sodium. According to FAO (2011) statistics, china is the world's leading producer of water melon. The top twenty leading producers of watermelon produced a collective volume approximately 92.7 million metric tons in 2011, of which china produced $75 \%$. Turkey, Iran and Brazil commanded a production share (of the 20 leading producers) of $4.7 \%, 3.5 \%$ and $2.4 \%$ respectively in 2011. Nigeria produced more watermelons in 2011 (139, 223 tons) than 
the leading fresh produce Africa exporter, Kenya, which produce 66,196 tons and south Africa that produce 77,993 tons (this day live, 2014). There are over 1,200 varieties of watermelon worldwide and quite a number of these varieties are also cultivated in Africa (Zohary and Hopf, 2000). The global consumption of the crop is greater than that of any other cucurbit.

Water melon is tropical or sub tropical plants needs temperature higher than $25^{\circ} \mathrm{C}$ $\left(77^{\circ} \mathrm{F}\right)$ to thrive. On a garden scale, the seeds are usually sown in pots under cover and transplanted into well drained sandy loam with a $\mathrm{PH}$ of between 5.5 and 7.7 with medium nitrogen levels.

The rinds of water melon which is outer greenish covering the edible nut most people avoid eating them due to their pickles (vegetable preserved in a solution usually brine or vinegar). The seeds of water melon have nutty flavor and can be dried and roasted or ground into flour. The juice can be into wine on its own or blended with other fruits. It is possible to make an alcoholic variant by pouring liquor into the hole in the rind of the whole fruit and eat the alcohol permeated flesh. The liquor filled is referred to as hard water melon.

The importance of water melon production is not limited to the general healthy additions. It aids weight loss and has been recommended for obese people and aid for others to maintain steady body growth. Also, it contributes to water in the skin and hair production of human with a wide range of medicinal effects in men. It is highly nutritious and thirst-quenching and also contains vitamin $C$ and $A$ in the form of disease-fighting betacarotene. Watermelon is rich in carotenoids, some of the carotenoids of which include lycopene, phytofluene, phytoene, betacarotene, lutein and nuerosporene. Lycopene and beta-carotene work in conjunction with other plant chemicals not found in vitamin/minerals supplements. Potassium is also available in it which is believed to help in the control of blood pressure and possibly prevention of stroke (De Lannoy, 2001). Lycopene is what gives water melon it's rich, red colour and is associated with reduced risk of developing muscular degeneration, prostate challenges, and a variety of 13 other degenerative conditions. Beta carotene is another powerful antioxidant that can help to protect body cells against damage by free radicals (Kim, 2008). Watermelon seeds are excellent sources of proteins (both essential and non-essential amino acids) and soil.

However, nutrition seems to be the least motivation for feeding consideration in Ekiti State. Nonetheless, the duality of water melon has not been explored to the maximum. So is the usefulness of its seed as observed. This under utilization has also contributed to the meager income and revenue accruable to the farmers than those of indigenous vegetables. Knowledge of aggregated farm level resources and difference in their productivities are essential in order to enhance productive capacity of small holding farmers (Ajewole and Folayan, 2008). (Ogundari and Ojo, 2005) argued that this would indicate direction of resource use adjustment and allocation.

The potential of watermelon as a cash-producing crop are enormous for farmers, especially those residing near the urban areas (Adekunle et al., 2003). Hence, this research examined in details, the compared cost and returns structure across the cropping system, pin-pointed the factors of affecting production level and efficiency of resources use.

Objectives of the Study. The general objective of the study was to determine the costs and returns of watermelon production in Ekiti State. The specific objectives were to:

- Examine the socio-economic characteristic of watermelon farmers in the study area.

- Estimate the cost and returns pattern of rural farmers with focus on water melon producers.

- Determine the efficient use of factors of production among water melon farmer the study area.

- Determine the production pattern and resources combination that will increase output and revenue of farmers in the study area. 


\section{METHODS OF RESEARCH}

The study was conducted in Ekiti state, Nigeria. The state is one of the states in the South Western Region of Nigeria. The state is within the tropics. The state was created on the $1^{\text {st }}$ of October, 1996 and comprises of 16 Local Government Area (LGAs). Ekiti state occupies land mass of approximately $6,3028 \mathrm{~km}^{2}$. Ekiti state has an estimated population of $2,432,543$ (NPC,2006). Ekiti State is located between latitudes $7^{\circ} 25^{\prime}$ and $8^{\circ} 05^{\prime} \mathrm{N}$ and between longitude $4^{\circ} 45^{\prime}$ and $5^{\circ} 46^{\prime} \mathrm{N}$ East. Ekiti state is predominantly an agricultural area whose main cash crops are cocoa, timbers, oil-palm and kolanuts. The food crops grown are cassava, yam, cocoyam and grain crops such as maize and rice. The state has two main seasons i.e. the rainy season and dry season.

Data Collection. Primary data was used for the study. Data was collected from the respondents with the aid of well-structured questionnaire. The information that was obtained included socio-economic characteristics of the respondents, the cost and returns pattern of rural farmers and the production pattern and resources combination.

Sampling Techniques. A multi-stage sampling technique will be use to select respondents for the study. At first stage, three local government area (LGAs) will be purposively selected based on their level of produce in the state which include lkole, ljero and Moba, at second stage three communities will be randomly selected from each local government, at the third stage 10 watermelon farmers will be selected also at random from the list of watermelon farmers in each of the communities. Thus a total of 120 respondents were surveyed for the study.

Data Analysis. Both descriptive statistics and quantitative methods were used in the survey. A well-constructed farm budget analysis was used to estimate the production cost, revenue and gross margin accruable to the farmers. The equation below was used to estimate the various parameters:

$$
\begin{gathered}
G M=T R-T V C \\
T C=T F C+T V C \\
N P=T R-T C
\end{gathered}
$$

Where: $\mathrm{TC}=$ Total Cost, $\mathrm{TFC}=$ Total Fixed Cost, $\mathrm{TVC}=$ Total Variable Cost, $\mathrm{GM}=$ Gross Margin,

TR = Total Revenue, NP = Net Profit.

Stochastic Frontier. The model was employed to examine the factors influencing output of watermelon among farmers in the study area and the technical efficiency of output and resources available to the farmer. The production function was defined stochastically as:

$$
Q=F(X I \beta) \exp (V 1-U i)
$$

Where: $Q=$ Quantity of watermelon produced, $X 1=$ Vector of input quantities, $\beta=$ Vector of parameters to be estimated, Exp $=$ Exponential function, $\mathrm{V} 1=$ Random variables; $\mathrm{Ui}=$ Non negative random variables which account for technical inefficiency in production.

The technical efficiency was calculated using:

$$
\begin{gathered}
T E i=Y i=F(X 1) \exp (V 1-U i) \\
Y i^{*} F(X 1) \exp (V 1) \\
T E=\exp (-U i)
\end{gathered}
$$

Where: $Y \mathrm{i}=$ Actual output, $\mathrm{Yi}^{*}=$ Potential output (frontier output). 


\section{RESULTS AND DISCUSSION}

Socio-economic Characteristics of the Respondents. Table 1 revealed that $65 \%$ of the respondents were male and the remaining $35 \%$ were female. This indicates that male were more involved in watermelon production than female in the study area.

From the table it also shows that age bracket of farmers in the study area revealed that $26.7 \%$ of the respondents are less than or equal to 20 years, $25.8 \%$ are between $21-30$ years while $20.0 \%$ of the respondents are within $31-40$ years and $27.5 \%$ are greater than 40 years. This finding reveals that most of the farmers are below 50 years of age indicating that they are still full of energy which will enhance better production of watermelon in the study area.

Table 1 - Socio-economic Characteristics of the Respondents

\begin{tabular}{|c|c|c|}
\hline Variables & Frequency & Percentage \\
\hline \multicolumn{3}{|c|}{ SEX } \\
\hline Male & 78 & 65 \\
\hline Female & 42 & 35 \\
\hline Total & 120 & 100 \\
\hline \multicolumn{3}{|l|}{ AGE } \\
\hline$\leq 20$ & 32 & 26.7 \\
\hline $21-30$ & 31 & 25.8 \\
\hline $31-40$ & 24 & 20 \\
\hline$\geq 40$ & 33 & 27.5 \\
\hline Total & 120 & 100 \\
\hline \multicolumn{3}{|l|}{ MARITAL STATUS } \\
\hline Single & 42 & 35.0 \\
\hline Married & 59 & 49.17 \\
\hline Divorced & 9 & 7.5 \\
\hline Widowed & 10 & 8.3 \\
\hline Total & 120 & 100 \\
\hline \multicolumn{3}{|c|}{ EDUCATIONAL QUALIFICATION } \\
\hline Primary & 17 & 14.2 \\
\hline Secondary & 47 & 39.2 \\
\hline OND/NCE or Equivalent & 15 & 12.5 \\
\hline HND/B.SC & 19 & 15.8 \\
\hline Postgraduate & 8 & 6.7 \\
\hline No Education & 14 & 11.7 \\
\hline Total & 120 & 100 \\
\hline \multicolumn{3}{|c|}{ HOUSEHOLD SIZE } \\
\hline $1-4$ & 36 & 30.0 \\
\hline $5-8$ & 62 & 51.7 \\
\hline$\geq 9$ & 10 & 17.5 \\
\hline Total & 120 & 100 \\
\hline \multicolumn{3}{|c|}{ FARM SIZE } \\
\hline$\leq 5$ & 46 & 38.8 \\
\hline $5.1-10.0$ & 52 & 43.3 \\
\hline$\geq 10.0$ & 22 & 18.3 \\
\hline Total & 120 & 100 \\
\hline \multicolumn{3}{|c|}{ FARMING EXPERIENCE } \\
\hline$\leq 1$ & 29 & 24.2 \\
\hline $2-5$ & 56 & 46.7 \\
\hline $6-10$ & 26 & 18.3 \\
\hline$>10$ & 12 & 10 \\
\hline Total & 120 & 100 \\
\hline
\end{tabular}

Source: Field survey, 2014.

The marital status of the respondents revealed that $35 \%$ of the respondents are single, $49.17 \%$ are married, while $7.5 \%$ are divorced and $8.3 \%$ are widowed. This implies that most of the respondents are married and thus they can help each other and utilize family labour to enhance watermelon production in the study area. 
Table 1 also revealed the educational status of the respondents, it was observed that $39.2 \%$ have secondary education, $12.5 \%$ have equivalents of OND/NCE, $15.8 \%$ have HND/BSC, $6.7 \%$ have post graduate education, $11.7 \%$ have no education, and $14.2 \%$ have primary education. This indicates that most of the farmers in Ekiti state are literate and can read and write which might make the adoption of improved technology that may increase the yield of watermelon.

Table 1 shows that $30.0 \%$ of the respondents have family size of between 1 and 4 , $51.7 \%$ have between 5 and 9 while $17.5 \%$ have family size greater than 10 .The large proportions of the farmers have family size between 5 and 9 which will help the farmers in finding solutions to problems associated with shortage of labour utilization in the study area.

Table 1 also revealed that $38.3 \%$ of the farmers had a farm size of $\leq 5 \mathrm{ha}, 43.3 \%$ had a farm size of $5-10$ ha, while $18.3 \%$ had a farm size of $\geq 10$ ha. This indicates that most of the watermelon farmers in the study area are still stick to the subsistence method of farming, hence farming on a relatively small area of farm land.

Table 1 shows that $24.2 \%$ of the farmers have farming experience of less than or equal to 1 year, $46.7 \%$ have experience of $2-5$ years, $18.3 \%$ have been farming for a period of $6-10$ years and $10.0 \%$ have experience of over 10 years. This indicates that farmers in the study area have the necessary experience to increase their watermelon production given a considerable level of inputs.

Cropping System of Watermelon Farmers. Table 2 shows the cropping system adopted by watermelon farmers. Item 1 shows that $65 \%$ of the respondents plant solely watermelon as against $35 \%$ of the respondents intercropped. Item 2 reveals that $66.67 \%$ of the 42 respondents intercropped watermelon with cassava, $19.05 \%$ and $9.52 \%$ intercropped with maize and tomato respectively while the remaining $4.76 \%$ intercropped with pepper. However, only $7.14 \%$ of the respondents who practice the intercropping did so to increase soil fertility as $33.33 \%$ planted other crops because of optimum land use. $50 \%$ of the respondents intercropped for economic reasons i.e. increase income and $9.52 \%$ did so to reduce crop failure.

Table 2 - Cropping System Utilized by Watermelon Farmers

\begin{tabular}{|c|c|c|c|c|}
\hline $\mathrm{S} / \mathrm{N}$ & Items & Options & Freq & $\begin{array}{l}\text { Percent } \\
\text { age }\end{array}$ \\
\hline 1 & What cropping system do you use? & $\begin{array}{c}\text { Sole cropping (water melon alone) } \\
\text { Water melon intercrop }\end{array}$ & $\begin{array}{l}78 \\
42\end{array}$ & $\begin{array}{l}65 \% \\
35 \%\end{array}$ \\
\hline 2 & What do you intercrop with water melon? & $\begin{array}{l}\text { Water melon+ cassava } \\
\text { Water melon+ maize } \\
\text { Water melon+ tomato } \\
\text { Water melon+ pepper }\end{array}$ & $\begin{array}{l}28 \\
8 \\
4 \\
2\end{array}$ & $\begin{array}{l}66.67 \% \\
19.05 \% \\
9.52 \% \\
4.76 \%\end{array}$ \\
\hline 3 & Why do you intercrop? & $\begin{array}{l}\text { To increase income } \\
\text { To improve soil fertility } \\
\text { To reduce crop failure } \\
\text { Optimum use of land }\end{array}$ & $\begin{array}{c}21 \\
3 \\
4 \\
14\end{array}$ & $\begin{array}{c}50 \% \\
7.14 \% \\
9.52 \% \\
33.33 \%\end{array}$ \\
\hline 4 & $\begin{array}{l}\text { Water melon planting method do you } \\
\text { employ in planting? }\end{array}$ & $\begin{array}{l}\text { Direct seedling } \\
\text { Transplanting }\end{array}$ & $\begin{array}{c}111 \\
9\end{array}$ & $\begin{array}{l}92.5 \% \\
7.5 \%\end{array}$ \\
\hline 5 & How much do you pay as rent on land? & $\begin{array}{c}\text { Inherited land } \\
\text { Less than } 2,000 \\
\text { Between } 2,100-10,000 \\
\text { Between } 11,000-20,000 \\
20,000 \text { and above }\end{array}$ & $\begin{array}{l}25 \\
12 \\
16 \\
39 \\
28\end{array}$ & $\begin{array}{c}20.83 \% \\
10 \% \\
13.34 \% \\
32.5 \% \\
23.33 \%\end{array}$ \\
\hline
\end{tabular}

Source: Field Survey, 2014.

Majority of the watermelon farmers in the study area sow their seeds directly $(92.5 \%)$ and only $7.5 \%$ transplant seedling of water melons. In item5, $20.83 \%$ of the farmers inherited the land they cultivates as this show that the primitive land acquisition system which has great effect on the scale of farming is still common in the study area. $23.33 \%$ of the farmer paid more than $\# 20,000$ for rent per annum, $10 \%$ of them paid less than $\# 2,000$ and $13.34 \%$ 
of them paid between $\# 2,100-10,000$ for the land and $32.5 \%$ of them paid between $\# 11,000$ 20,000 for the land rent.

Cost and Returns Analysis of Watermelon Production. Table 3 shows the cost and return analysis of watermelon production in the study area. The table below shows that watermelon producers in the study area has a net profit of \#75,114.68. This clearly shows that there is a high return rate on the water melon production and the average rate of return is \#2.0 ceteris paribus, every \#1 invested in water melon production will yield \#2.50. Hired labour cost more and it represents the most expensive variable input. It also shows that watermelon production is labour intensive as typical of agricultural production and this conforms to the findings of Adeoye et al., (2011). The cost structure also suggests that water melon production is profitable.

Table 3 - Cost and Returns Analysis

\begin{tabular}{|c|c|c|c|c|}
\hline $\mathrm{S} / \mathrm{N}$ & Variables & Average quantity/ha & Unit price (\#) & Value (\#) \\
\hline \multicolumn{5}{|c|}{1 Gross returns } \\
\hline & Average yield & 625 & 200 & 125,000 \\
\hline \multicolumn{5}{|c|}{2 Inputs } \\
\hline 1 & Variable input (cost) & & & \\
\hline$A$ & Seeds $(\mathrm{kg})$ & 0.45 & 100 & 45 \\
\hline$B$ & Fertilizer (kg) & 23.5 & 212.77 & 5000.09 \\
\hline $\mathrm{C}$ & Chemicals (kg) & 1.35 & 2592.59 & 3499.99 \\
\hline $\mathrm{D}$ & Land (ha) & 1 & 1650 & 1650 \\
\hline $\mathrm{E}$ & Labour (man/day) & 34.38 & 800 & 27504 \\
\hline \multicolumn{5}{|c|}{ II Fixed input (cost) } \\
\hline A & Cutlass & & & 105.37 \\
\hline$B$ & Hoe & & & 1650 \\
\hline C & Sprayer & & & 4515 \\
\hline $\mathrm{D}$ & Tractor & & & 7350 \\
\hline & Total input cost $=1+I \mid$ & & & 49885.32 \\
\hline \multicolumn{5}{|c|}{3 Gross margin analysis } \\
\hline A & $\mathrm{GM}=\mathrm{I}-\sum 2 \mathrm{I}$ & & & $87,300.92$ \\
\hline$B$ & $\mathrm{TC}=\mathrm{TVC}+\mathrm{TFC}$ & & & 49.885 .32 \\
\hline $\mathrm{C}$ & $N P=1-3 B$ & & & $75,114.68$ \\
\hline
\end{tabular}

Source: Field Survey, 2014.

Table 4 - Estimated Production Frontier

\begin{tabular}{|c|c|c|c|}
\hline Variable & Parameter & coefficient & t-value \\
\hline Technical efficiency & & & \\
\hline Constant & $\beta_{0}$ & 8.60 & $33.84^{* *}$ \\
\hline Seed quantity & $\beta_{1}$ & -2.73 & -5.90 \\
\hline Farm size & $\beta_{2}$ & 1.05 & $4.74^{* * *}$ \\
\hline Fertilizer & $\beta_{3}$ & -1.15 & -2.69 \\
\hline Labour & $\beta_{4}$ & -0.79 & -4.33 \\
\hline Technical inefficiency function & & & \\
\hline Constant & $\delta_{0}$ & -20.89 & $-1.56^{* *}$ \\
\hline Age & $\delta_{1}$ & 0.07 & $3.03^{* *}$ \\
\hline Family size & $\delta_{2}$ & -1.38 & -2.12 \\
\hline Level of education & $\delta_{3}$ & -0.64 & 2.07 \\
\hline
\end{tabular}

Source: Field Survey, 2014; **significant at 5\% ; ${ }^{* *}$ significant at $10 \%$.

Table 5 - Efficiency Distribution

\begin{tabular}{|c|c|c|}
\hline Efficiency & No. of farmers & Percentage \\
\hline $20-29.99$ & 35 & $29.17 \%$ \\
\hline $30-39.99$ & 14 & $11.67 \%$ \\
\hline $40-49.99$ & 31 & $25.83 \%$ \\
\hline $50-59.99$ & 40 & $33.33 \%$ \\
\hline Total & 120 & 100 \\
\hline
\end{tabular}

Source: Field Survey, 2014. 
The result of stochastic frontier production in table 4 shows that the coefficient of the farm size was positive and significant suggesting that a percentage increase in the size of the farm will lead to an increase of $1.05 \%$ in yield. It also showed that coefficient of labour used is negative and not significant. An increase in labour supply will reduce value of output by $0.79 \%$ as farmers in this area rely majorly on hired labour. This correlates with the findings of Ogundari and Ojo (2005). Also, the quantity of seeds has a negative coefficient as it is the quality of seeds that matters. If correct seed rates and quality seed are not used, output will be low even if other inputs are in abundance (Ogundari and Ojo 2005) and this tallies with the finding of Ajibefun and Daramola, (2001) and Schippers, (2000).

The estimate coefficient of family size indicates that it is negative but not significant. The negative value of inefficiencies suggests that they have positive correlation. This explains that the 0.07 coefficient of age reduces the efficiency of a farmer as they age on. it is also significant at $5 \%$. However, the level of education is not significant but it reduces the technical inefficiencies of the farmers in the study area.

\section{CONCLUSION}

It was observed that the production of water melon in Ekiti state is profitable with a high percentage of the respondents in the study area having good percentage of technical efficiency. However, there is need for the farmers to increase their scale of operation as farm size is important in the productivity of farmers.

\section{RECOMMENDATIONS} made:

Based on the findings of this research work, the following recommendations were

- The land acquisition system that makes it hard for farmers to acquire agricultural should be reviewed to allow the farmers have more land to cultivate.

- Provision of improve seeds for cultivation should be made available to the farmers.

- Government grants and loans should be made easy to access as this will reduce the cost incurred on inputs and help provide funds for the production activities.

- There should be an intensive research work into the area of water melon production to help provide information that will make the production easy.

\section{ACKNOWLEDGEMENTS}

The effort of Sarumi Abayomi Tajudeen is hereby commended during the data collection process of this study.

\section{REFERENCES}

1. Adeoye I.B., Olajide-Taiwo F.B., Adebisi-Adelani O., Usman J.M and Badmus M.A (2011).

2. Economic analysis of water melon based production system in Oyo state Nigeria ARPN Journal of Agricultural and Biological Science. Vol 6(7) 1990-6145.

3. Agricultural Performance Survey of 2010 Wet Season in Nigeria by NAERLS and NPAFS (2010): States Agricultural Performance Survey NAERLS Report No. 003, pp137, 142, 144.

4. Ajewole O.C and Folayan J.A (2008). Stochastic Frontier Analysis of Technical Efficiency in dry season leaf vegetable production among small holders in Ekiti State, Nigeria. Agricultural Journal. 3(4): 252-257.

5. Ajibefun,I.A and Daramola,A.G (2001). Measurement and Sources of Technical Inefficiency in Poultry Egg Production in Ondo State, Nigeria Journal of Economics and Rural Development. 14(1): 252-257. 
6. De Lannoy, (2001). Crop Production in Tropical Africa. Romain H.R (Ed). Published by Directorate General for International Cooperation (DGIC), Brussels, Belgium. Pp.236238

7. FAO, (2011). Agricultural Statistics for 2011. Food and Agriculture Organization of the United Nations. http://apps.Foa.org/page/collections?subset=agriculture

8. FAO, 2011. United Nations, Food and Agriculture Organization, FAOSTAT (2011). FAO.Rome. http://faostat.org/site/567

9. Kim, B. (2008). Water Melon Nutrition: How to get the most nutrition value of watermelon. Health and beyond. http://www.chetday.com/index.html

10. NPC, ( 2006). National Population Census, Abuja Nigeria.

11. Ogundari K and S.O Ojo, (2005). The Determinant of Technical Efficient in Mixed Crop Production in Nigeria, a Stochastic Parameter Approach. Journal of Applied Tropical. Agriculture. 10:3-9

12. Pettinger T, (2010). Productive vs allocative efficiency / economic help.

13. Schippers, R.R (2000). African Indigenous Vegetable. An overview of the Cultivated Species Pp. 56-60 chatham, u.k., n.r/aco.eu.

14. This day live (2014). How Export Farm will improve Nigeria's foreign earnings. Media report www.thisdaylive.com/articles

15. Zohary D. and Hopf V. (2000). Domestication of Plants in the Old World. 3rd Ed. Oxford University Press. P 193. 